\title{
Yield and nutraceutical quality of tomato fruits in organic substrates
}

\section{Rendimiento y calidad nutracéutica de tomate en sustratos orgánicos}

\author{
Lilia Salas-Pérez ${ }^{1}$, José Luis García-Hernández ${ }^{2}$, Cándido Márquez-Hernández ${ }^{\dagger}$, Manuel Fortis-Hernández ${ }^{3}$, \\ Josué Raymundo Estrada-Arellano ${ }^{4}$, Juan Ramón Esparza-Rivera ${ }^{5}$, Pablo Preciado-Rangel ${ }^{3 *}$ \\ ${ }^{1}$ Universidad Politécnica de Gómez Palacio. Gómez Palacio, Durango, México \\ ${ }^{2}$ Facultad de Agricultura y Zootecnia-Universidad Juárez del Estado de Durango. Gómez Palacio, Durango, México \\ ${ }^{3}$ Instituto Tecnológico de Torreón. Torreón, Coahuila, México \\ ${ }^{4}$ Facultad de Ciencias Biológicas-Universidad Juárez del Estado de Durango. Gómez Palacio, Durango, México \\ ${ }^{5}$ Facultad de Ciencias Quimicas-Universidad Juárez del Estado de Durango. Gómez Palacio, Durango, México \\ *Autor de correspondencia: ppreciador@yahoo.com.mx
}

Scientific note received: January 05, 2016, accepted: May 31, 2016

\begin{abstract}
The objective of this study was to determine the proportion of sand, solarized manure, vermicompost and soil capable of increasing tomato fruit yield and lycopene content. The treatments were: T1: $80 \%$ Sand- $20 \%$ Vermicompost (SV), T2: $80 \%$ Sand- $20 \%$ Solarized manure (SSM1), T3: $80 \%$ Sand - $20 \%$ Pelite ?Steiner solution (SPSS), T4: $80 \%$ Sand- $5 \%$ Soil - $15 \%$ Vermicompost (SSoV), T5: $85 \%$ Sand - $15 \%$ Solarized manure (SSM2) and T6: $80 \%$ Sand - $5 \%$ Soil - $15 \%$ Solarized manure (SSoSM). The organic substrates T5, T4, T1 and the control (T3) obtained larger fruits and yields. The lycopene content in tomato fruits grown in the organic substrates was 26 $\%$ higher than that obtained in the control treatment. Organic fertilizers improve the nutraceutical quality of tomato fruits, without significantly degrading yield.
\end{abstract}

Keywords: organic fertilizers, lycopene, protected agriculture.

RESUMEN. El objetivo del trabajo fue determinar la proporción de arena, estiércol solarizado, vermicomposta y suelo, idónea para incrementar el rendimiento y el contenido de licopeno en frutos de tomate. Los tratamientos evaluados fueron T1: $80 \%$ Arena - $20 \%$ Vermicomposta (AV), T2: $80 \%$ Arena- $20 \%$ Estiércol solarizado (AES1), T3: $80 \%$ Arena - $20 \%$ Perlita - solución Steiner (APSS), T4: $80 \%$ Arena - $5 \%$ suelo - $15 \%$ Vermicomposta (ASV), T5: $85 \%$ Arena - $15 \%$ Estiércol solarizado (AES2) y T6: $80 \%$ Arena - $5 \%$ Suelo - $15 \%$ Estiércol solarizado (ASES). Los tratamientos T5, T4, T1: y el testigo (T3) fueron de mayor rendimiento y tamaño de fruto. El contenido de licopeno en los sustratos orgánicos superó en $26 \%$ al obtenido en el tratamiento testigo. Los abonos orgánicos mejoran la calidad nutracéutica del tomate, sin disminuir el rendimiento.

Palabras clave:abonos orgánicos, licopeno, agricultura protegida.

\section{INTRODUCTION}

The tomato (Solanum lycopersicum) is one of the most consumed vegetables (Al-Omran et al. 2010). In 2014, 52,374 ha of tomato were planted in Mexico (SIAP 2016), while in the Comarca Lagunera 949 ha were cultivated, of which 802 ha were cultivated under protected agriculture (SAGARPA 2015). In the country, protected agriculture is carried out on 21530 ha, of which 54.3 $\%$ are cultivated under shade netting and $45.7 \%$ in a greenhouse (SAGARPA 2015). Tomato production systems have been diversified in order to increase yield, incorporating technologies such as plastic covers, drip irrigation and hydroponics, obtaining yields of between 5 and $8 \mathrm{~kg} \mathrm{plant}^{-1}$, which is more than three times that obtained under open field conditions, where yields range between 1.5 and $2.0 \mathrm{~kg} \mathrm{plant}^{-1}$ (Jaramillo et al. 2006).

Due to the negative effect of fertilizers on the environment and their high prices, there is a 
strong need to look for alternatives such as organic fertilizers, among which manure, compost and vermicompost stand out (Fortis et al. 2013). The benefits of organic fertilizers as substrates are reported in studies by De la Cruz-Lázaro et al. (2009), De la Cruz-Lázaro et al. (2010), Márquez et al. (2013) and Moreno et al. (2014), who report having obtained safe tomatoes without the use of synthetic pesticides or fertilizers by using organic substrates such as compost, vermicompost, sand, sawdust and tezontle (Ortega et al. 2010).

Tomato is rich in vitamins $A$ and $C$, potassium and carotenoids such as lycopene, the latter being responsible for the red color in the fruit, which is used as a quality index (Candelas-Cadillo et al. 2005). Lycopene is an antioxidant that, once absorbed by the body, helps prevent and repair damaged cells. An important feature of tomato is lycopene accumulation as a physiological response to stress conditions during its development. These stress factors can be increased salinity, light intensity, temperature and/or nutrient limitation, among others (Guevara et al. 2005). Although there is a lot of information related to lycopene production, very little is known about the synthesis of this compound in response to the use of organic fertilizers. As a result, it is important to conduct research in order to establish the optimal conditions to achieve higher biomass productivity and nutraceutical quality (Bermudez et al. 2002). Therefore, the aim of this study was to determine the proportion of sand, solarized manure, vermicompost and soil suitable for increasing yield and lycopene content in tomato fruits.

\section{MATERIALS AND METHODS}

\section{Description of experimental site and crop de- velopment}

The experiment was set up at the Technological Institute of Torreon in Torreon, Coahuila, Mexico, located between $24^{\circ} 30^{\prime}$ and $27^{\circ} \mathrm{NL}$, and $102^{\circ} 00^{\prime}$ and $104^{\circ} 40^{\prime} \mathrm{WL}$, at an elevation of 1120 masl. The experiment was conducted in a metal-framed shade house with a flat roof, north-south orientation, and Raschel-type 30 $\%$ shade mesh. The variety evaluated was Sahel (Syngental ${ }^{\circledR}$ ), a saladette tomato of indeterminate growth. The density was 4 plants $\mathrm{m}^{2}$, placing a single plant in a $20-\mathrm{L}, 800$-gauge black plastic bag. The culture system was a stem, with weekly pruning, phytosanitary control performed preventively and using inputs approved by international standards for organic production (NOP 2002). A drip irrigation system was used; according to the phenlogical stage, the amount of water applied ranged between 0.5 and $2.0 \mathrm{~L} \mathrm{bag}^{-1}$. At the beginning of the anthesis of the flowers, pollination was performed mechanically every day between 12:00 and 14:00 h with an electric vibrator.

\section{Treatments}

Mixtures of organic fertilizers were made from livestock manure, compost, vermicompost and river sand. River sand was sterilized with a $5 \%$ hypochlorite solution. The treatments were formed by mixtures of organic fertilizers, which were: T1: $80 \%$ Sand - $20 \%$ Vermicompost (SV), T2: $80 \%$ Sand $20 \%$ - Solarized manure (SSM1), T3: $80 \%$ Sand - $20 \%$ Perlite - Steiner Solution (SPSS), T4: 80 $\%$ Sand - $5 \%$ Soil - $15 \%$ Vermicompost (SSoV), T5: $85 \%$ Sand - $15 \%$ Solarized manure (SSM2) and T6: $80 \%$ Sand - $5 \%$ Soil - $15 \%$ Solarized manure (SSoSM). Steiner nutrient solution (Stainer 1984) was prepared with highly soluble commercial fertilizers, with $\mathrm{pH}$ adjusted to 5.5 with sulfuric acid, and electrical conductivity (EC) of $2.0 \mathrm{dS} \mathrm{m}^{-1}$.

\section{Variables evaluated}

Fruit yield, fruit weight, polar and equatorial diameter, total soluble solids content and lycopene content in fruits were evaluated. Fruit yield was determined by the sum of the weight of all the fruits harvested at commercial maturity in each treatment, reporting it in $\mathrm{kg} \mathrm{plant}^{-1}$. Average weight, equatorial diameter and polar diameter were obtained in the fruits of five plants obtained from each treatment, which were measured with an AutoTEC ${ }^{\circledR}$ precision digital Vernier caliper. Fruit weight was determined as the average weight of all 
Álvarez-Holguín et al.

Nutraceutical quality and substrates in tomato

Esosist. Recur. Agropec.

4(10):169-175,2017

the fruits harvested in each treatment and weighed on an Ohaius Valor ${ }^{T M}$ balance. Soluble solids content was determined from a drop of macerated fruit obtained from each treatment, which was placed in an ATAGO refractometer.

Lycopene content was determined by the method of Barba et al. (2006). For lycopene extraction, $10 \mathrm{~g}$ of tomatoes at commercial maturity were taken from each treatment, to which a solution of tetrahydrofuran and methanol $(1: 1 \mathrm{v} / \mathrm{v}$ THF:MeOH) was added before the suspension was vacuum filtered. The filtrate was transferred to a separating funnel to which petroleum ether and a $10 \% \mathrm{NaCl}$ solution were added, and then mixed by stirring. Then the top layer of petroleum ether was washed with $100 \mathrm{ml}$ of distilled water. The ether fraction was transferred to a 50-ml flask and evaporated to dryness in a Napco vacuum oven for $14 \mathrm{~h}$ at absolute pressure of $60 \mathrm{~mm} \mathrm{Hg}$ at $50{ }^{\circ} \mathrm{C}$. The residue was dissolved in $6 \mathrm{ml}$ of hexane. Then the filtrate was filtered and analyzed by high performance liquid chromatography (HPLC) on a Agilent 1100 Series chromatograph, into which a reversedphase $\mathrm{C}_{18}$ Supelco Discovery column $(15 \mathrm{~cm} \times 4.6$ $\mathrm{mm}$ and $5 \mu \mathrm{m}$ ) was installed. An isocratic mobile phase system composed of acetonitrile:methanol: 2-propanol (38:60:2 v/v/v) was used. The flow rate was $1 \mathrm{ml} \mathrm{min}{ }^{-1}$ by injecting $20 \mu \mathrm{l}$ of the sample. Lycopene was quantified at a wavelength of 470 $\mathrm{nm}$. Lycopene identification was based on the retention time of the Sigma lycopene standard. The concentration of the standard was $50 \mu \mathrm{g} \mathrm{ml}^{-1}$. The whole process was conducted under reduced light. Lycopene content was calculated based on the relationship between the known concentration of the standard and the corresponding peak area, to report it as $\mathrm{mg}$ of lycopene per $100 \mathrm{~g}$ fresh weight ( $\mathrm{mg}$ $100 \mathrm{~g}^{-1} \mathrm{FW}$ ).

\section{Experimental design and statistical analysis}

Treatments were evaluated under a completely randomized experimental design with ten replicates. Results were analyzed by analysis of variance using the SAS statistical software package, and mean comparison was performed with the Tukey test $(p \leq 0.05)$

\section{RESULTS AND DISCUSSION}

Statistical differences among the evaluated treatments were found. The control (T3) and organic substrates $\mathrm{T} 5, \mathrm{~T} 4$ and $\mathrm{T} 1$ had the largest yields with an average of $3.13 \mathrm{~kg} \mathrm{plant}^{-1}$ (Figure 1), confirming that organic substrates can have yields similar to that obtained with nutrient solution. In this regard, Márquez et al. (2006) mention that the use of organic fertilizers as substrate components can obtain a good yield in the first tomato cuts, while Rodríguez et al. (2009) indicate that an inert substrate (sand), fertilized with compost tea, obtains similar yields to tomato crops fertilized in a traditional manner. On the other hand, De la Cruz-Lázaro et al. (2009) and (2010) point out differences in yield between inorganic fertilization and organic substrates. These differences can be associated with the differential response of crops to the type and proportion of organic fertilizer used as substrate (Lazcano et al. 2009). The ability of an organic substrate to improve the physical, chemical and nutritional properties of a crop depends on its source and proportion in the growth medium (Chaoui et al. 2003).

Statistical analysis for total soluble solids content ( ${ }^{\circ}$ Brix) and equatorial diameter showed no statistical difference among treatments, indicating that the control and the treatments containing mixtures of organic substrates behaved similarly (Table 1 ), while in the variables fruit weight and polar diameter statistical differences were detected; the heaviest fruit weight was obtained by treatments T5, T4, T1 and T3 (control), which had an average weight of $0.325 \mathrm{~kg}$. This indicates that the organic substrates used can produce similar fruit weight characteristics as the control treatment. In this regard, other research studies indicate better crop development and yield by using less than $30 \%$ compost as a mixture component (Atiyeh et al. 2000), which probably improves the physical properties of the substrate (Hernández et al. 2008) and the gradual release of nutrients (Ao et al. 2008), thereby fa- 


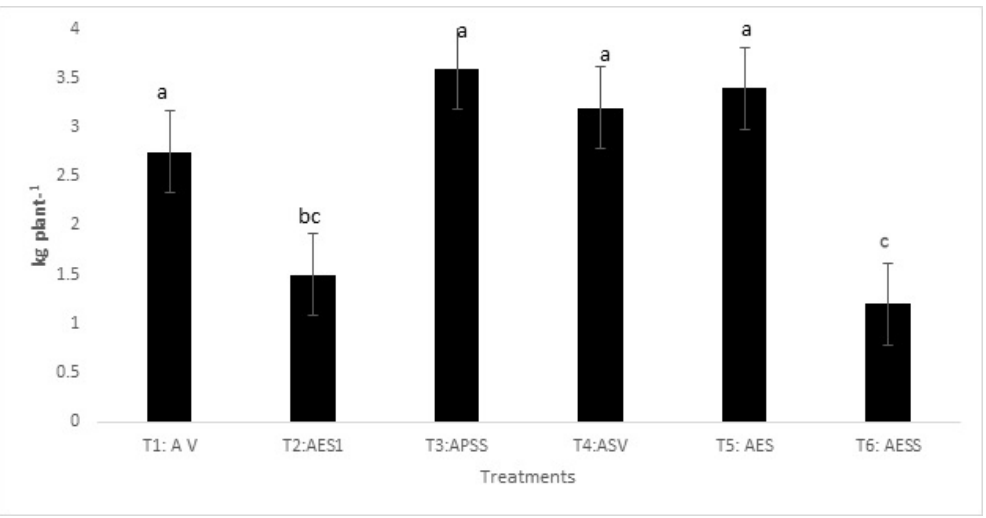

Figure 1. Average tomato yield in pots with mixtures of organic substrates. Different letters indicate statistical difference (Tukey, $P \leq 0.05$ ). The lines on the bars represent the standard error of the mean.

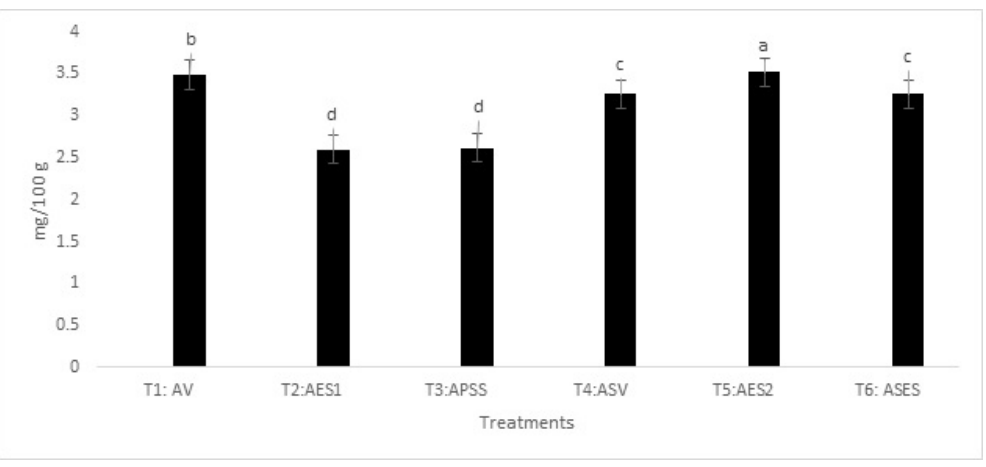

Figure 2. Average lycopene content values in tomato fruits. Different letters between columns indicate differences (Tukey, $\mathrm{P} \leq 0.05$ ). The lines on the bars represent the standard error of the mean.

Table 1. Average values of fruit weight, total soluble solids content, equatorial and polar diameter of tomato fruit produced in organic substrates.

\begin{tabular}{lcccc}
\hline Treatments & $\begin{array}{c}\text { Fruit weight } \\
\mathrm{kg}\end{array}$ & $\begin{array}{c}\text { Total soluble solids } \\
{ }^{o} \text { Brix }\end{array}$ & \multicolumn{2}{c}{ Diameter $\mathrm{cm}$} \\
Polar & Equatorial \\
\hline T1: AV & $0.270 \mathrm{ab}$ & 4.07 & $6.230 \mathrm{ab}$ & 4.17 \\
T2: AES1 & $0.140 \mathrm{~b}$ & 3.82 & $5.875 \mathrm{ab}$ & 4.05 \\
T3: APSS & $0.283 \mathrm{ab}$ & 4.82 & $4.725 \mathrm{c}$ & 4.48 \\
T4: ASV & $0.360 \mathrm{a}$ & 4.77 & $5.400 \mathrm{bc}$ & 4.21 \\
T5: AES2 & $0.390 \mathrm{a}$ & 3.85 & $6.475 \mathrm{a}$ & 4.57 \\
T6: ASES & $0.103 \mathrm{~b}$ & 3.07 & $5.312 \mathrm{bc}$ & 4.05 \\
\hline
\end{tabular}

Different letters within each column indicate significant statistical difference (Tukey, $\mathrm{P} \leq 0.05$ )

voring the presence of natural hormones such as bio-stimulants, growth regulators and humic acids (Azarmi et al. 2008).

The fruits of plants in organic substrate mixtures had the largest polar diameter, which is an indicator of pericarp thickness (Coelho et al. 2003). Fruits produced in treatments $\mathrm{T} 5, \mathrm{~T} 1$ and $\mathrm{T} 2 \mathrm{had}$ the highest polar diameter values, averaging 6.19 $\mathrm{cm}$, which is similar to that reported by Marquez et al. (2013), who found values between 5.9 and 6.3 $\mathrm{cm}$ in tomato fruits produced with organic substrate mixtures.

Figure 2 shows that four of the organic substrate mixtures had the highest lycopene con- 
tent values, averaging $3.45 \mathrm{mg} 100 \mathrm{~g}^{-1}$ of lycopene, $26 \%$ higher than the control treatment (T3) and similar to the figures reported by Arias et al. (2000) who determined the lycopene content in slightly red tomato fruits. Overall, in tomato fruits, the lycopene concentration varies between 3.0 and 12.2 $\mathrm{mg} 100 \mathrm{~g}^{-1}$ depending on the stage of fruit ripening (Martínez-Valverde (2002). In this respect it is known that lycopene content varies with fertilization, harvest time, variety and environmental conditions (Waliszewski and Blasco 2010). In this regard the use of organic fertilizers, due to having an excess of soluble salts, can cause stress that increases the metabolism of carotenoids; concerning this, López-Elias et al. (2013) found that the concentration of total carotenoids increased by reducing the concentration of nitrogen. Possibly the level of concentration and availability of this element in the organic mixtures used stimulated the production of carotenoids. The use of organic fertilizers in a shade netting system can reduce dependence on chemical fertilizers, increasing the yield and improving the quality of tomato fruits.

\section{ACKNOWLEDGEMENTS}

We thank Mexico's National Science and Technology Council (CONACYT) for granting a scholarship to Dr. Cándido Márquez-Hernández ${ }^{\dagger}$ for his sabbatical stay.

\section{LITERATURE CITED}

Al-Omran AM, Al-Harbi AR, Wahb-Allah MA, Nadeem M, Al-Eter A (2010) Impact of irrigation water quality, irrigation systems, irrigation rates and soil amendments on tomato production in sandy calcareous soil. Turkish Journal of Agriculture and Forestry 34: 59-73.

Ao Y, Sun M, Li Y (2008) Effect of organic substrates on available elemental contents in nutrient solution. Bioresource Technology 99: 5006-5010.

Arias R, Lee TCh, Logendra L, Janes H (2000) Correlation of lycopene measured by HPLC with the L, a, b color reading of a hydroponic tomato and the relationship of maturity with color and lycopene content. Journal of Agricultural Food Chemistry 48: 1697-1702.

Atiyeh RM, Edwards CA, Subler S, Metzger JD (2000) Earthworm-processed organic wastes as components of horticultural potting media for growing marigold and vegetable seedlings. Compost Science and Utilization 8: 215-223.

Azarmi R, Sharifi ZP, Satari M (2008) Effect of vermicompost on growth, yield and nutrient status of tomato (Lycopersicom esculentum). Pakistan Journal Biological Science 1: 1797-1802.

Barba AIO, Cámara HM, Sánchez MMC, Fernández RV, López SM (2006) Application of a UV-vis detection HPLC method for a rapid determination of lycopene and b-carotene in vegetables. Food Chemistry 95: 328-336.

Bermudez JL, Lodeiros C, Morales E (2002) Biomass production of the marine microalga Chroomonas sp. as a function of $\mathrm{pH}$, luminic intensity, and salinity. Boletín de Investigaciones Marinas y Costeras 31 : 167-185.

Candelas-Cadillo MG, Alanís-Guzmán MGJ, Bautista-Justo M, Del Río-Olague F, García-Díaz C (2005) Contenido de licopeno en jugo de tomate secado por aspersión. Revista Mexicana de Ingeniería Química 4: 299-307.

Chaoui HI, Zibilske LM, Ohno T (2003) Effects of earthworm casts and compost on soil microbial activity and plant nutrient availability. Soil Biology and Biochemistry 35: 295-302. 
Coelho EL, Fontes PC, Finger FL( 2003) Qualidade do fruto de melão rendilhado em função de doses de nitrogênio. Bragantia 62: 173-178.

De la Cruz-Lázaro E, Estrada-Botello MA, Robledo-Torres V, Osorio-Osorio R, Márquez-Hernández C, Sánchez-Hernández R (2009) Producción de tomate en invernadero con composta y vermicomposta como sustrato. Universidad y Ciencia 25: 59-67

De la Cruz-Lázaro E, Osorio-Osorio R, Martínez-Moreno E, Lozano-del Río J, Gómez-Vázquez A, SánchezHernández R (2010) Uso de compostas y vermicompostas para la producción de tomate orgánico en invernadero. Interciencia 35: 363-368.

Fortis HM, Preciado RP, García HJL, Navarro-Bravo A, Antonio GJ, Omaña SJM (2012) Sustratos orgánicos en la producción de chile pimiento morrón. Revista Mexicana de Ciencias Agrícolas 3: 1203-1216.

Guevara M, Lodeiros C, Gómez O (2005) Carotenogénesis de cinco cepas del alga Dunaliella sp. (Chlorophyceae) aisladas de lagunas hipersalinas de Venezuela. Revista de Biología Tropical 53: 331-337.

Hernández MGI, Salgado GS, Palma LDJ, Lagunes E, Ruiz RO (2008) Vinaza y composta de cachaza como fuente de nutrientes en caña de azúcar en un gleysol mólico de Chiapas, México. Interciencia 33: 855-860.

Jaramillo J, Rodríguez VP, Guzmán M, Zapata M (2006) El cultivo de tomate bajo invernadero. Corpoica, Centro de Investigación La Selva, Rionegro. Antioquia, Colombia. 48p.

Lazcano C, Arnold J, Tato A, Zaller J, Domínguez J (2009) Compost and vermicompost as nursery pot components: effects on tomato plant growth and morphology. Spanish Journal of Agricultural Research. 7: $944-951$.

López-Elías JA, D Fimbres- Olivarria, LA Medina-Juarez, A Miranda Baeza,m LR Martínez-Córdova, DMA Molina-Quijada (2013) Producción de biomasa y carotenoides de Dunaliella tertiolecta en medios limitados en nitrógeno. Revista Internacional de Botánica Experimental 82: 23-30

Márquez HC, Cano RP, Chew MYI, Moreno RA, Rodríguez DN (2006) Sustratos en la producción orgánica de tomate cherry bajo invernadero. Revista Chapingo Serie Horticultura 12: 183-189.

Márquez HC, Cano RP, Figueroa VU, Avila DJA, Rodríguez DN, García HJL (2013) Rendimiento y calidad de tomate con fuentes orgánicas de fertilización en invernadero. Revista Internacional de Botánica Experimental 82: 55-61.

Martínez-Valverde I, Periago MJ, Provan G, Chesson A (2002) Phenolic compounds, lycopene and antioxidant activity in commercial varieties of tomato (Lycopersicum esculentum). Journal of the Science of Food Agriculture 82: 323-330.

Moreno RA, García GL, Cano RP, Martínez CV, Márquez HC, Rodríguez DN (2014) Desarrollo del cultivo de melón (Cucumis melo) con vermicompost bajo condiciones de invernadero. Ecosistemas y Recursos Agropecuarios 1: 163-173.

NOP (2002) National Organic (Program Programa Nacional Orgánico), Reglamento Final. 7CFR Parte 205 Programa Nacional Orgánico. Departamento de Agricultura de Estados Unidos, http://organicrules.org/ 398/1/US_NOP_2002_10_en.pdf. Date consulted: november 10, 2015.

Ortega MLD, Sánchez OJ, Díaz RR, Ocampo MJ (2010) Efecto de diferentes sustratos en el crecimiento de plántulas de tomate (Lycopersicum esculentum Mill). Ra Ximhai 6:365-372.

Rodríguez DN, Cano RP, Figueroa VU, Favela CE, Moreno RA, Márquez HC, et al. (2009) Uso de abonos orgánicos en la producción de tomate en invernadero. Terra Latinoamericana 27: 319-327. 
SAGARPA (2015) Anuario estadístico. SAGARPA Región Lagunera. Lerdo, Durango. Avance de siembras y cosechas. Disponible en http://www.siap. sagarpa.gob.mx. Data consulted: may 5, 2015.

SIAP (2016) Servicio de Información Agroalimentaria y Pesquera SIAP (2016), Anuario Estadístico Agroalimentaria y pesquera http://www.siap.gob.mx/cierre-de-la-produccion-agricola-por-cultivo/. Data consulted: january 5, de 2016.

Steiner AA (1984) The universal nutrient solution. Proc. 6th Int. Cong. on Soilless Culture. ISOSC. Lunteren, Holanda. pp: 633-649.

Waliszewski KN, Blasco G (2010) Nutraceutical properties of lycopene. Salud Pública de México 52: 254-265. 
